\title{
THE ETHNOBOTANY OF THE EGYPTIAN EASTERN DESERT: A COMPARISON OF COMMON PLANT USAGE BETWEEN TWO CULTURALLY DISTINCT BEDOUIN GROUPS
}

STEVEN M. GOODMAN ${ }^{a}$ and JOSEPH J. HOBBS

'Museum of Zoology, The University of Michigan, Ann Arbor, Michigan 48109 and ${ }^{b} 1406$ Folts, Austin, Texas 78704 (U.S.A.)

(Accepted January 29, 1988)

\section{Summary}

A comparison is made between 21 species of plants used in common by two culturally distinct Bedouin groups living in different areas of the Eastern Desert of Egypt, the Bischarin and the Khushmaan Ma'aza. We document how plants are utilized by each culture for nutritional, medicinal, and functional (utilitarian) purposes and aim to investigate if these uses arose independently through a parallel experimentation process or were learned by one tribe from the other. The data suggest that between these two Bedouin groups the utilization of at least 19 of the 21 plant species was independently derived. On the basis of linguistic grounds the use of two plants may have been introduced to the Bischarin by Arabic-speaking people.

\section{Introduction}

Some important questions in understanding the evolution of plant resource utilization are whether or not independent cultures use the same basic floral components in similar ways; and whether similar patterns of usage reflect a parallel experimentation process or are based on chance. Analogous plant usage, of independent origin, by culturally distinct and geographically disjunct groups, would be evidence of a common logical, stepwise experimentation process.

The flora of the eastern Sahara, particularly in some coastal and mountain portions, is remarkably similar at both the generic and species level across a vast area (Kassas and Zahran 1962, 1965, 1971). This region is occupied by nomadic groups of independent cultural origin, and thus it provides an excellent setting for comparing similarities and differences in the uses of plants.

This paper documents and compares the utilization of plants common to 
the ranges of two different Bedouin groups living in the Eastern Desert of Egypt, the Bischarin and the Khushmaan Ma'aza. We review here only those plants exploited by both groups. Thus, we deal specifically with the small subset of the ethnobotany known to these Bedouins for which cross-cultural comparisons can be made.

There has been some previous work on the plant-resource utilization by these two Bedouin groups. Tregenza's $(1955,1958)$ keen observations as a naturalist and detailed descriptions of plant use by Khushmaan are important contributions. Some mention is made in the works of Drar (1936) and Fahmy (1936) on how the Bischarin exploit plants. Murray (1935) provides some useful details on plant utilization by different Bedouin groups throughout Egypt. Osborn (1968) discusses generic "Bedouin" uses of plants with little reference to particular tribes. More comprehensive works dealing with wider geographical portions of North Africa include Bellakhdar (1978) and Boulos (1983).

\section{The Cultures}

The Bischarin are of Hamitic origin and belong to a larger cultural group known as the Beja. Their unwritten language, Tu Bedawie, is of the northern Cushitic family group. Approximately one-third of the Bischarin, predominantly men who have contact with Nile Valley culture, speak some Arabic. Numerous Arabic words occur in their spoken language.

The Bischarin territory spans the Egyptian-Sudanese border and is approximately enclosed by the Red Sea to the east; the Nile Valley to the west; $24^{\circ} \mathrm{N}$. Lat. (Berenice) to the north; and $19^{\circ} 40^{\prime} \mathrm{N}$. Lat. (Port Sudan) to the south (Fig. 1). The badana or section of the Bischarin living in this area is the Hamedorab. It is not known when the Bischarin first occupied this region, but the group as known today has been there at least since the first century A.D. (Paul, 1954). There is some evidence that the Bischarin's ancestors were akin to the predynastic ancient Egyptians (Keimer, 1951, 1952, 1953). Today a portion of the Bischarin are practising Muslims.

Those Bischarin that continue the nomadic tradition obtain most of their subsistence as pastoralists; they herd sheep, goats, and camels. The yearly peregrinations of the Hamedorab often halt for the winter in highland areas, such as Gebel Elba. At such places late autumn/winter rains fill their pasture and water needs for several months (Goodman, 1985).

The Khushmaan are members of one of the approximately 20 clans that comprise the Ma'aza tribe. They are Muslims of Semitic origin and speak an Arabic dialect similar to that used by Bedouins in the northwestern Arabian Peninsula, from where their ancestors began migrating to Egypt 200 years ago. The Khushmaan are nomads who move their herds of sheep, goats and camels to ephemeral pastures in the northern portion of the Eastern Desert.

Their operational environment is the Ma'aza tribal territory, encompassing about $90,000 \mathrm{~km}^{2}$, bounded on the west by the Nile Valley and the east 


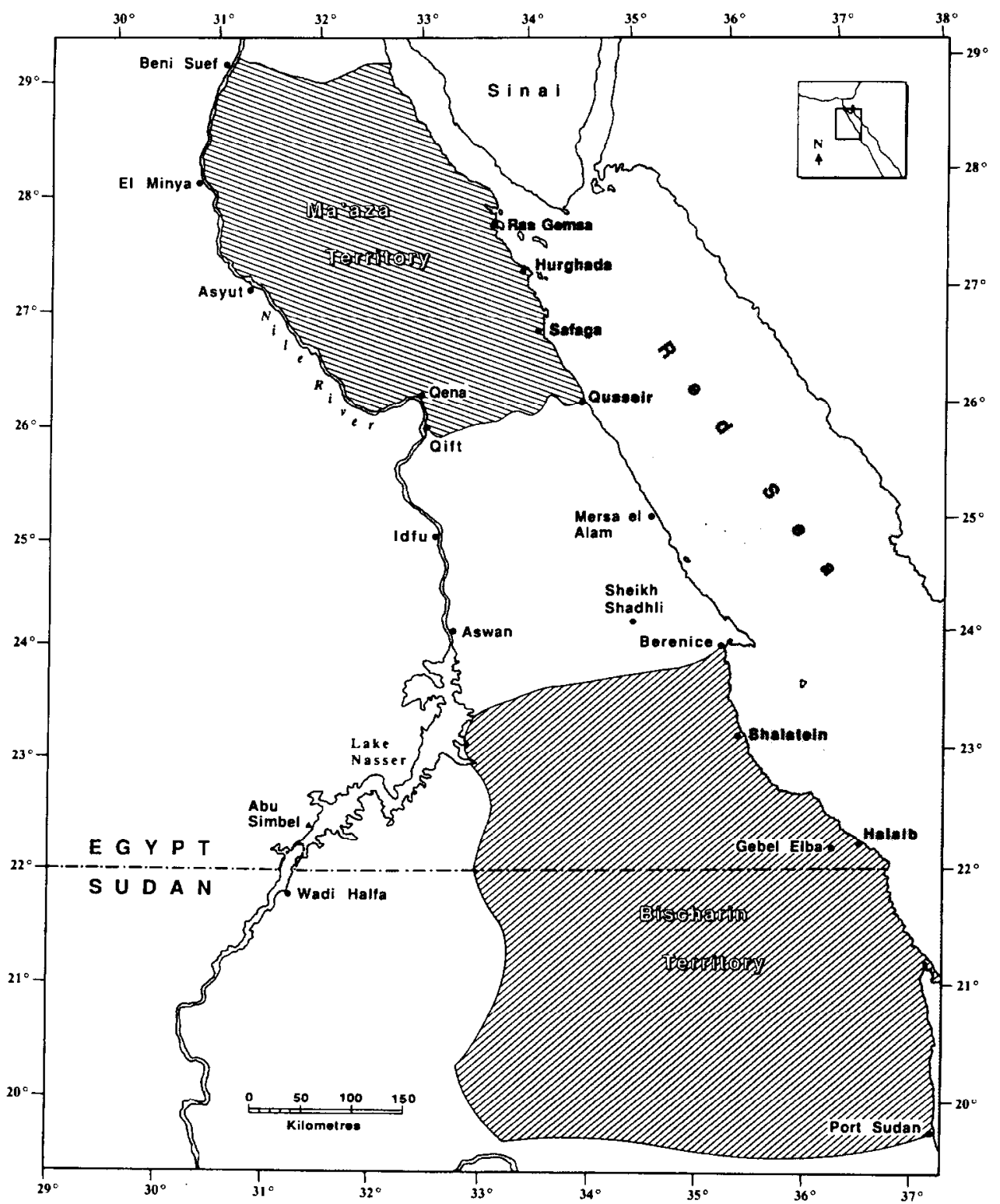

Fig. 1. Map of the Bischarin and Ma'aza tribal territories in the Egyptian Eastern Desert and Sudanese Red Sea Mountains.

by the Red Sea and Gulf of Suez. The northern limit is Wadi Araba $\left(29^{\circ} \mathrm{N}.\right)$ and the adjoining plain leading west to the Nile Valley; this boundary is approximately demarcated by the Zafarana - El Koriamat road. The southern boundary is the road from Qift, in the Nile Valley, to Qusseir, on the Red 
Sea coast (approximately $26^{\circ}$ N.) (Fig. 1). At present the Khushmaan have more interactions with non-tribal peoples than the Bischarin, most notably in villages and small settlements along the Red Sea coast and in the Nile Valley; however, pastoral nomadism remains the economic foundation of Khushmaan life (Hobbs, 1986).

The flora

The vegetation of the Egyptian Eastern Desert is depauperate. Vast portions of the region are devoid of any plant cover, particularly in the north. The higher plant concentrations tend to be in wadi bottoms, on shaded mountain slopes, and in deep canyons. As one moves from north to south there is a notable increase in the density and species diversity of plants (Kassas and Zahran, 1962, 1965, 1971). This pattern is related in part to an increase in both the quantity, spatial distribution, and regularity of precipitation. Most of the Eastern Desert plants are characteristic members of the Saharo-Sindian phytogeographical region (sensu Eig, 1931/32). The major exception is in the extreme south at Gebel Elba, in Bischarin country, where numerous Afrotropical plant species reach their northern limit (Kassas and Zahran, 1971). The floristic diversity in the Bischarin territory is approximately twice that of the Khushmaan territory, and includes many more species of trees.

\section{Materials and methods}

Since 1980 we have been conducting independent and joint field research in the Eastern Desert of Egypt. Part of this program has involved working and travelling with Bedouins, during which time we have gathered information on local plant utilization and made collections of the flora. When known we have included the local plant name(s) and in some cases terms for various plant parts and products. Some general knowledge on local natural history as explained by our Bedouin informants has also been added.

SMG is responsible for the information gathered on Bischarin ethnobotany. This data was principally obtained by interviews and collaborative collecting with two people: the late Mohamed Awad, a nomadic Bischari locally famous for his knowledge of the flora, and his son, Hassan Mohamed Awad, a partially settled Bischari that still keeps animal herds and regularly travels to the desert as a guide and to collect herbs. The majority of the plants used by the Bischarin were collected in the Gebel Elba vicinity (Fig. 1). The travel range of these two informants was approximately $400 \mathrm{~km}$ in any direction from Gebel Elba. As the Bischarin plant terms belong to the unwritten language of $\mathrm{Tu}$ Bedawie, they are difficult to transliterate; this has generally been done phonetically. A few Bischarin names have been extracted from Schweinfurth (1869) and sources cited herein.

JJH gathered the information on the Khushmaan Ma'aza use of local 
plants. The chief Khushmaan informant, Saalih 'Ali, was chosen on the basis of his being the reputed "naturalist" of the Khushmaan. However, up to 20 other Khushmaan men were interviewed about their knowledge of plant uses. There were no significant differences in individuals' knowledge. The material presented in this paper represents knowledge apparently shared by all Khushmaan men. Khushmaan plant names are given in romanized form. The transliteration system follows Hobbs (1986).

Voucher plant material collected by SMG is deposited in the Missouri Botanical Gardens (MO), St. Louis, and the Cairo University Herbarium (CAI). These plants did not receive individual field numbers. Instead, they were collected by locality number. Thus, voucher material is cited as, "MO: locality 1, Gebel Elba, Wadi Aideib" meaning a specimen identified as the respective taxon and collected at locality 1, Gebel Elba, Wadi Aideib, is housed in the Missouri Botanical Gardens. Plants obtained by JJH throughout the Ma'aza tribal territory are deposited in the National Research Center (CAIRC), Dokki, Egypt, and in a duplicate private collection held by $\mathrm{JJH}$. These voucher specimens received individual field numbers, which are cited in the text. The systematic order and nomenclature follows Täckholm (1974). Synonyms that appear in the older literature on medicinal plants of the region have been included.

\section{Results}

MORACEAE

Ficus pseudosycomorus Decne.

syn. Ficus palmata Forssk.

Bischarin: Local name: kun'te. The fig fruits (teen, from the Arabic) are rich in carbohydrates and are consumed as food. The finer branches of the tree are hollowed out and used as stems for hand-carved stone pipes. (Voucher specimen - CAI: locality 2, Gebel Abraq.)

Khushmaan: Local name: hammaat. The fruits are eaten. It is important to refrain from eating the ripe figs between $0.5-1 \mathrm{~h}$ after harvesting them; the latex they exude is a powerful irritant to skin and mucous glands which apparently degrades quickly. People only eat the female figs, although Nubian ibex (Capra ibex) consume the male figs.

The branches of the tree are used for numerous purposes, i.e. as poles to support the classical bayt ash-sha'ar or wool tent of the Ma'aza and as "scarecrows" to keep Nubian ibex from drinking at open water sources. (Voucher specimen - CAIRC: JJH 40, 202.)

\section{POLYGONACEAE}

Rumex vesicarius L.

syn.Acetosa vesicaria (L.). Löve

Bischarin: Local name: ak. Young fresh leaves are consumed as a pot-herb. (Voucher specimen - MO: locality 10, Red Sea Governorate, Bir Gahaleya.)

Khushmaan: Local name: himaadh. Like the Bischarin, the Khushmaan eat both the leaves and stems. (V̄oucher specimen - CAIRC: JJH 142.) 
MORINGACEAE

Moringa peregrina (Forssk.) Fiori

syn. Moringa aptera Gaertn.

Bischarin: Local name: ba'handi. The ripe seed pods are gathered, the seeds removed, and an oil used for cooking extracted. No evidence was found that the seed pods or seeds were exported by the Bischarin to the Nile Valley for sale.(Voucher specimen - MO:locality 2, Gebel Elba, Wadi Aideib.)

Khushmaan: Local name: yasar. A type of semna (cooking oil) is made from the seeds (baan). In the autumn the Khushmaan harvest baan for sale in the folk apothecaries of the Nile Valley, where the seeds are known as habba ghalia or fustuq baan. The seeds also have laxative properties, particularly when eight or more are consumed. The bark (ghaylda) produces a red, water-fast dye used for clothing. Various parts of the woody portions are used, i.e. branches for pipe stems and the hardwood for hoes. (Voucher specimen - CAIRC: JJH 16, 193, 315.)

\section{CAPPARIDACEAE}

Capparis decidua (Forssk.) Edgew.

syn. Capparis aphylla Roth

Bischarin: Local name: hanboaq, sarwab. The ripe fruits are consumed for their nutritional value. (Voucher specimen - CAI: locality 3, Gebel Elba, Wadi Serimtai.)

Khushmaan: Local name: tundhub. The fruit, balaha tundhub, is cooked and eaten. The seeds must first be removed, as they induce vomiting if eaten. The plant has no local medicinal purpose. The wood is used in the dalfa portion of the basuur camel saddle. (Voucher specimen - CAIRC: JJH 83, 216.)

Capparis cartilaginea Decne.

syn. Capparis galeata Fres.

Bischarin: Local name: not recorded. The fruits are eaten as food. They are also used as a remedy against fever and headache. (Voucher specimen CAI:locality 10, Red Sea Governorate, Bir Gahaleya.)

Khushmaan: Local name: lassaf. The pulp of the ripe fruit (jaru) is eaten for its nutritional value. The dried fruits are the main ingredient of a nutritious, spicy drink called mariida, which can be kept in a waterskin for 1-2 months. No evidence was found that the Khushmaan eat the fruits of Capparis spinosa L. (syn. C. aegyptia Lam.) (contra Osborn, 1968). A poultice to combat rheumatism is made by cooking the fruits with salt and vegetable oil, letting the mash cool, and then applying it to the painful area. Tregenza (1955) mentioned that the leaves of a caper bush were used as a component in a cold remedy; Osborn's (1968) identification of the plant as $C$. spinosa is presumably in error and the species used is almost certainly $C$. cartilaginea. (Voucher specimen - CAIRC: JJH 209.) 


\section{CLEOMACEAE}

Cleome droserifolia (Forssk.) Delile

Bischarin: Local name: ark'a. An infusion of this plant is used as a remedy for skin eruptions (Fahmy, 1936). (Voucher specimen - CAI: locality 10, Red Sea Governorate, Bir Gahaleya.)

Khushmaan: Local name: mashta. An infusion is employed as a cough suppressant. It is also administered as a remedy against the larvae of the adhgat botfly (Oestrus ovis); the female fly sprays the larvae directly on the human face and they then burrow under the skin. This cure, however, is of no use for the eyes. The leaves of the plant are sometimes rubbed in the moustache and hair for their pleasant smell; one Bedouin companion remarked, "it is like cologne". The foliage is thought to repel ticks; Khushmaan informants claim that a camel will often make straight for this plant, rubbing its head in the greenery to rid itself of vermin. The Khushmaan believe this behavior accounts for the name of this plant, after masht, meaning "comb".(Voucher specimen - CAIRC: JJH12.)

\section{LEGUMINOSAE}

Cassia italica (Mill.) Lam. ex Steud.

syn. Cassia obovata Collad.

Bischarin: Local name: amberki, merara. An infusion prepared from the leaves is used as a purgative. (Voucher specimen - MO: locality 1, Gebel Elba, Wadi Aideib.)

Khushmaan: Local name: sanna. No part of this plant is eaten or used for medicinal purposes by the Khushmaan. They gather the plant and its seeds for export to the Nile Valley, where it is used as a purgative, particularly in cases of habitual constipation (Mahran, 1967). (Voucher specimen - CAIRC: JJH 204.)

\section{Acacia raddiana Savi}

syn. Acacia tortilis (Savi) Brenan

Bischarin: Local name: sangan'eb or sayaal (the latter presumably of Arabic origin). The sap exude of this tree is occasionally used as food. The woody tissue, or bast, is exceptionally strong and is employed in the making of various types of cordage. The ripe pods of this species, called ollaaf, are important fodder for domestic animals, particularly during the dry summer months.

The Bischarin use Acacia in the tanning of domestic and wild animal hides. The principal species used is A. etbaica Schweinf. (arat) and to a lesser extent also $A$. raddiana. Small branches and ripe seed pods are removed from the tree and allowed to dry. The bark, leaves, and seed pods are then wrapped in cloth and the whole lot is submerged in a basin filled with water. The tannins leach out of the Acacia pieces within a couple of days; the skin is then immersed in the liquid and dried numerous times. When the dried 
hide remains flexible, it has been properly tanned. (Voucher specimens MO: locality 5, Red Sea Governorate, Gebel Abraq; MO: locality 11, Gebel Elba, Wadi Kansisrob; and MO: locality 13, Gebel Elba, Wadi Akwamtra.)

Khushmaan: local name: sayaal (Fig. 2). The red gum (samgh) of the tree is eaten. A small branch is broken to allow the gum to issue forth; the accumulation is later scraped off and eaten. The practice does not harm the tree.

The shaved bark, known as najub, is used in tanning waterskins made from the hides of Nubian ibex. The bark is boiled and cooled, the skin staked out with the hair side down, the najub solution poured on to the hide several times over the course of a few days, and the skin is left to dry.

The leaves of $A$. raddiana provide an important source of food for domestic stock; however, when the leaves are bright green, at the ribba stage, they may be poisonous to herd animals. The wood of this tree is used for multiple purposes: the branches as poles in the traditional bayt ash-sha'ar tents; the branches as mahjan sticks (used to shake seed pods from Acacia trees); and the wood in camel saddles. (Voucher specimen - CAIRC: JJH 23, 195.)

\section{Acacia ehrenbergiana Hayne}

syn. Acacia flava (Forssk.) Schweinf.

Bischarin: Local name: delaaw or sallam (the latter presumably of Arabic

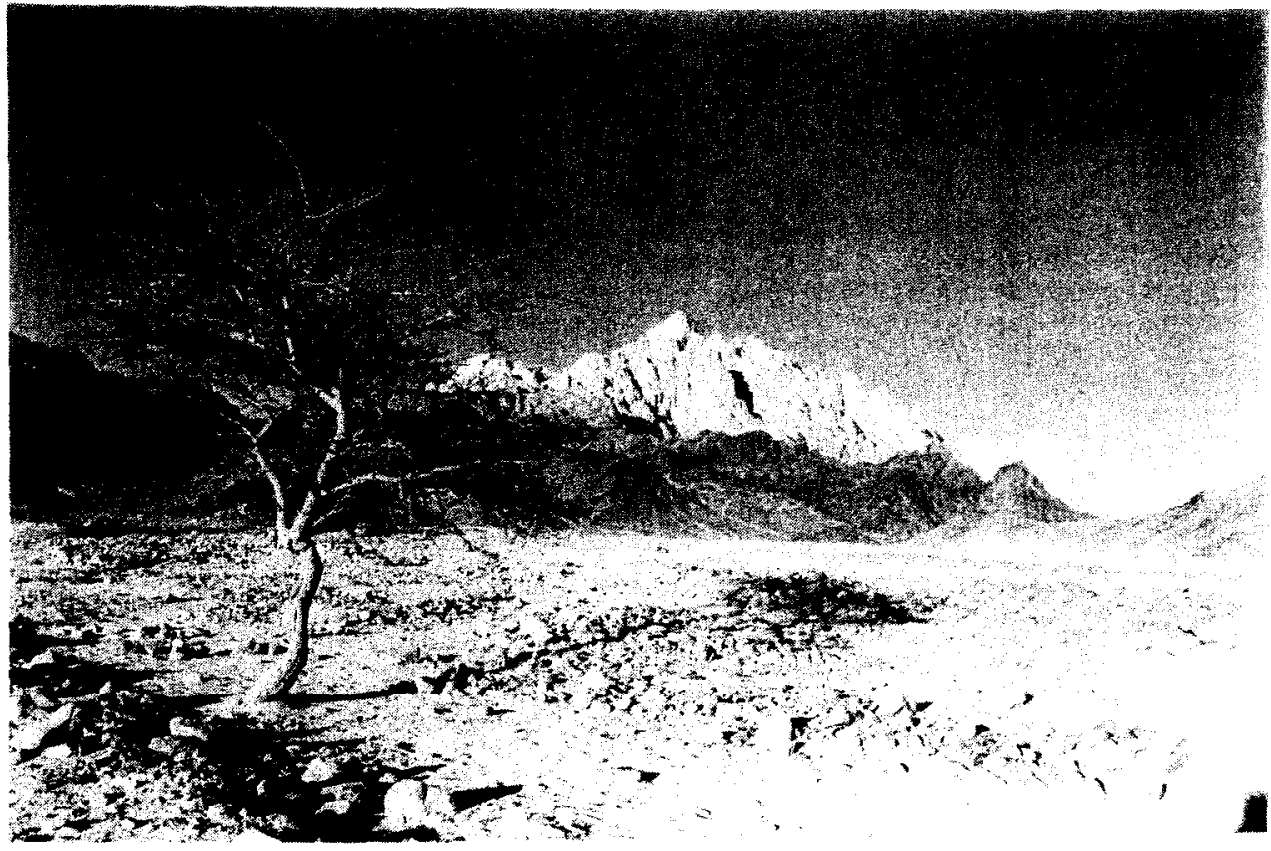

Fig. 2. Acacia raddiana in Wadi Abu Abid. The mountain in the background is Egypt's highest outside of Sinai, Gebel Shayib al-Banat $(2187 \mathrm{~m})$. Photograph taken by JJH on December 6, 1982. 
origin). The roots of this tree are used in the 'alam style of walking stick. (Voucher specimen - CAI: locality 10, Red Sea Governorate, Bir Gahaleya.)

Khushmaan: Local name: sallam. The mirkaad walking stick is fabricated out of the tree's branches. (Voucher specimen - CAIRC: JJH 34.)

\section{SALVADORACEAE}

Salvadora persica L.

Bischarin: Local name: $u$ 'hib, also sometimes referred to as mik'a. The fruits and leaves are occasionally eaten. The leaves have a slightly pungent and spicy flavor. A syrup made from the ripe fruits is used to grease skins so as to make them impervious to liquids. An extract from the seeds produces a bright green oil that is employed as a varnish for finishing wood tools. Portions of the fibrous twigs are severed into $10-30 \mathrm{~cm}$ lengths and used as tooth-brushes (miswaak, from the Arabic). (Voucher specimen CAI: locality 6, Gebel Elba, Wadi Kansisrob.)

Khushmaan: Local name: araak. The fruits (balah al-araaka) are eaten for their nutritional value. An infusion of the leaves is used to treat urinary retention or hasar. If the tea is drunk in the afternoon, preferably without sugar, it clears the urinary tract. The Khushmaan recognize an infusion of araak as a useful treatment for bilharzia when contracted by Nile Valley dwellers. The Khushmaan also collect branches of this plant as miswaak tooth-brushes, both for local use and sale in the Nile Valley. (Voucher specimen - CAIRC: JJH 64.)

\section{RHAMNACEAE}

Ziziphus spina-christi (L.) Willd.

Bischarin: Local name: ga'baat. The fruits (dah'ga'baat) are consumed for their nutritional value. (Voucher specimen - CAI: locality 7, Gebel Elba, Wadi Aideib.)

Khushmaan: Local name: sidr. They eat the fruits (nabak) of the five individuals of this tree known to grow in their territory. They attribute the presence of these trees at a Roman road-station to Roman cultivators (Fig. 3). (Voucher specimen - CAIRC: JJH 98, 298c.)

\section{CUCURBITACEAE}

Citrullus colocynthis (L.) Schrad.

syn. Colocynthis vulgaris Schrad.

Bischarin: Local name: si'nab, hamissin'at. No evidence was found that the Bischarin consume the seeds or pulp of this plant as food. The bitter tasting seeds taken from the gourd-like fruits are used as a drastic purgative, sometimes for its anthelmintic properties. They also contain an insect repellent, particularly useful against moths, and are placed amongst clothes to deter insect damage. A black tar-like substance extracted from the seeds is used to treat skin disease, mostly sarcoptic mange in camels. (Voucher specimen - CAI: locality 4, Gebel Elba, Wadi Aideib.) 


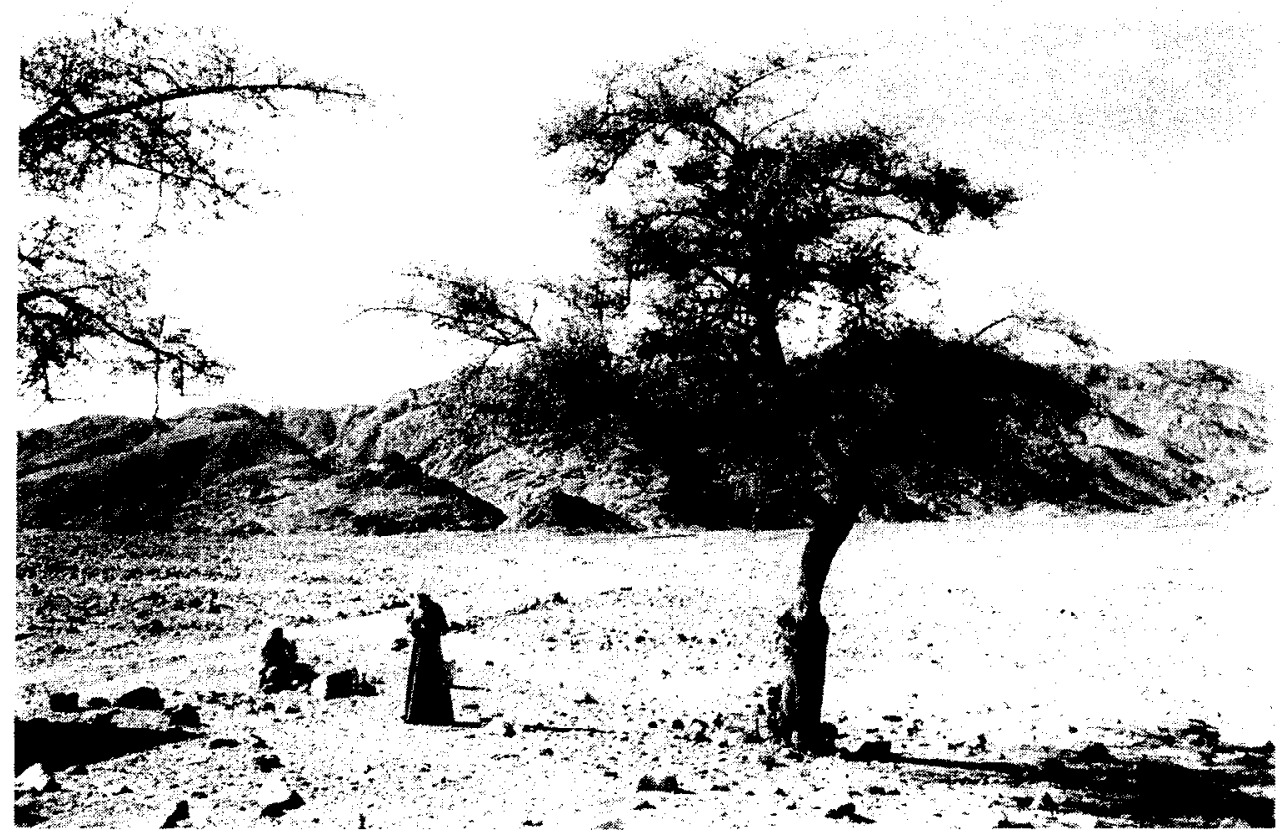

Fig. 3. Khushmaan Bedouins and the small grove of Ziziphus spina-christi in Wadi Umm Sidr, at a Roman way-station on the Via Porphyrites. Photograph taken by JJH on November 28, 1982.

Khushmaan: Local name handhal. The Khushmaan are also well aware of the purgative properties of handhal. However, it is a small piece of pulp (rather than seeds) which when consumed produces watery evacuations within five minutes of ingestion.

Handhal is used to treat rheumatism. The method of application seems to vary. Techniques employed by Egyptians, i.e. non-Bedouin Nile Valley dwellers, include: placing cut halves of the green gourd on both heels of the feet, ending treatment when the patient tastes bitterness in the mouth; making a poultice by cutting one or two gourds into pieces, frying them in cooking oil, boiling the mixture for $10 \mathrm{~min}$, and then placing it on the skin; or putting the cut halves of a green gourd directly on coals until heated and then applying the hot half directly to the heel of the foot, where it "sucks out" the pain.

The ash of burned dry gourds is imbued into the fabric of tinder-cloth used in the flint and steel fire-starting method of az-zinaad. (See Tregenza (1955) for a detailed description of the production and use of this tool.) The contemporary Khushmaan do not use this plant either for tanning waterskins (contra Osborn, 1968) or for food (contra Tregenza, 1955; Osborn, 1968). (Voucher specimen - CAIRC: JJH 66.) 


\section{ASCLEPIADACEAE}

Solenostemma argel (Del.) Hayne

Bischarin: Local name: harjal (from the Arabic). An infusion of the leaves is used as a laxative. (Voucher specimen - CAI: locality 2, Gebel Elba, Wadi Hareitra.)

Khushmaan: Local name harjal. The fruits are not eaten. An infusion of the plant is used to relieve stomach ailments. The leaves are harvested by trimming them off the stem, which does not destroy the plant (Fig. 4). Harjal is exported for sale to the Nile Valley, where it is used as a purgative in the treatment of colic (Mahran, 1967). The charcoal derived from this plant is used in the production of the fire starting tool, in a similar way to the Citrullus gourd. (Voucher specimen - CAIRC: JJH 41.)

\section{Calotropis procera (Ait.) Ait.}

Bischarin: Local name: bires, umberes. The plant contains a viscous latex that possesses strong vesicatory properties. The latex is also used as a fermenting agent in the production of marrisa, a beer made out of dates. The silky seed fibres are used for stuffing pillows and camel saddle cushions. The root of this plant is used in the making of the Bischarin headrest (mitir'as)

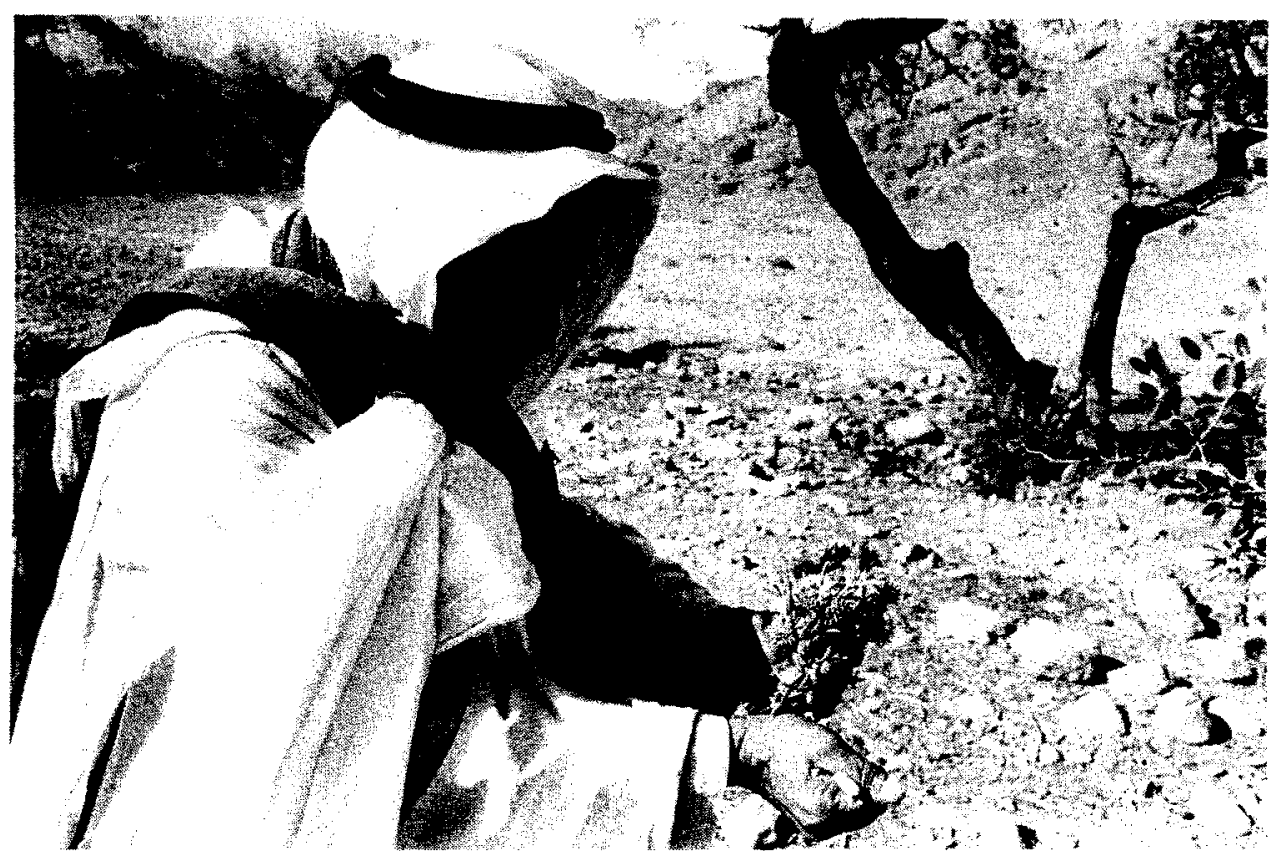

Fig. 4. Khushmaan Bedouin Sulimaan Mara'i with freshly cut Solenostemma argel in Wadi Umm Sidr. The tree in the immediate right foreground is Ziziphus spina-christi. Photograph taken by JJH on November 28, 1982. 
(Murray, 1935). (Voucher specimen - MO: locality 13, Gebel Elba, Wadi Akwamtra.)

Khushmaan: Local name: 'ushar. The latex milk is applied to the skin to relieve itching; if placed in the eyes it causes immediate blindness. In former times the charcoal derived from this plant was an essential ingredient of Ma'aza gunpowder. (Voucher specimen - CAIRC: JJH not numbered.)

\section{Pergularia tomentosa L.}

syn. Daemia cordata (Forssk.) R. Br. ex Schult.

Bischarin: Local name: ha'atoay. The ingested leaves are known to induce both vomiting and diarrhoea. (Voucher specimen - CAI: locality 10, Red Sea Governorate, Bir Gahaleya.)

Khushmaan: Local name: ghaylga. Members of the clan have heard about the use of this plant in treating hemorrhoids, but are unfamiliar with the technique described by Osborn (1968). The Khushmaan do no use ghaylga themselves for any medical or nutritional purpose. (Voucher specimen CAIRC: JJH 138.)

\section{SOLANACEAE}

Solanum nigrum L.

Bischarin: Local name: not recorded. A mash of the plant is used against heart and liver ailments. It is not exactly clear how it is consumed, but apparently an infusion of the leaves is drunk. The fruits have strong purgative properties. The fruits of the related species $S$. unguiculatum A. Rich (oli-leef) are used to poison predators that are reputed to take young lambs and goats; between 20 and 30 fruits are placed in dead animals and when scavengers feed on the carcass they consume the poison. One of the principal target species is the Lappet-faced Vulture (Torgos tracheliotus). (Voucher specimens - CAI: locality 7, Gebel Elba, Wadi Aideib (nigrum) and CAI: locality 6, Gebel Elba, Wadi Akwamtra (unguiculatum).)

Khushmaan: Local name: 'anab adh-dhiib, from the Arabic meaning "the jackal's grapes". It is reported that $S$. nigrum fruits are not poisonous if eaten; nowever, the Khushmaan do not consume them. (Voucher specimen CAIRC: JJH 18, 302.)

Hyoscyamus boveanus (Dun. in DC.) Asch. ex Schweinf.

Bischarin: Local name: not recorded. The flowers of members of the genus are occasionally mixed with other herbs or tobacco and smoked for their intoxicating properties. None of the Bischarin with whom this plant was discussed had actually smoked it, an activity to which there is a strong social stigma. (Voucher specimen - CAI: locality 10, Red Sea Governorate, Bir Gahaleya.)

Khushmaan: Local name: saykaraan, from the Arabic root meaning "to become intoxicated". This plant is not presently used by the Khushmaan; they still gather it in limited quantities for sale in the Nile Valley markets. In former times a few well-remembered individuals smoked the leaves for 
their mind-altering effects. Nubian ibex eat the leaves of the plant without any apparent effects. (Voucher specimen - CAIRC: JJH 48, 318.)

COMPOSITAE

Pulicaria undulata (L.) Kostel.

Bischarin: Local name: not recorded. The leaves are used to flavor tea and water for a porridge dish known as asida. (Voucher specimen - CAI: locality 4, Gebel Elba, Wadi Aideib.)

Khushmaan: Local name: rabl also occasionally as shaay jabali. An infusion of the leaves forms a tea substitute. (Voucher specimen - CAIRC: JJH 8.)

Launaea nudicaulis (L.) Hook.

Bischarin: Local name: riba heilaab. The young leaves are eaten as a potherb. (Voucher specimen - CAI: locality 10, Red Sea Governorate, Bir Gahaleya.)

Khushmaan: Local name: huwwi. The leaves are also consumed as food. (Voucher specimen - CAIRC: JJH 71, 240.)

\section{LILIACEAE}

Asphodelus fistulosus L.

syn. Asphodelus tenuifolius Cav.

Bischarin: Local name: busseil (Täckholm and Drar, 1954). The seeds are used as a diuretic. The young leaves are eaten as a pot-herb. (Voucher specimen - MO: locality 16, Gebel Elba, Wadi Akwamtra.)

Khushmaan: Local name: bawrag. The Khushmaan eat the raw leaves and stems of this plant. (Voucher specimen - CAIRC: JJH 133.)

\section{PALMAE}

Phoenix dactylifera L.

Bischarin: Local name: teb'blook'ten'dij or nakhl (the latter from the Arabic). The food value of dates (blook) is considerable, the fruit being rich in carbohydrates, although lacking fat and proteins. The leaf-sheath fibre is used as a filter in the making of jebenna, a strong coffee drink. The wood and fronds of this palm and Hyphaene thebaica (L.) Mart. (dom) are used for a multitude of devices and construction materials. (Voucher specimen CAI: locality 2, Red Sea Governorate, Wadi Gemal.)

Khushmaan: Local name: nakhl. The fruits of $P$. dactylifera are widely harvested and consumed as food. The palm fibre (liif) is used to make camel hobble ropes (gayd) and camel halters (rasan). The mid-rib of the fronds (hadhafiira) is modified to support the seam of the waterskin (girba). (No voucher JJH specimen.)

\section{Discussion}

Plants of 21 species were found to be used by both the Bischarin and the 
Khushmaan. The types of utilization fall into three distinct groups: nutritional, medicinal, or functional (utilitarian). Numerous plant species had multiple uses both within and between these three groups. Out of the 21 species, the Bischarin used $12(57 \%)$ nutritionally, ten $(48 \%)$ medicinally, and seven $(33 \%)$ for utilitarian purposes, compared to the Khushmaan usage of $12(57 \%)$, nine $(43 \%)$, and ten $(48 \%)$, respectively (Table 1$)$. Although we attempted to comprehensively document the ethnobotanical traditions practiced by the Bischarin and Khushmaan some information remains incomplete, particularly for plant species not shared between the regional floras of the two groups. Due to strict segregation between the sexes in both the Bischarin and Khushmaan, it was not possible for the researchers to interview women. Thus, we feel it is inappropriate to present any other numerical analysis until further data is available. However, with the present information, several interesting patterns emerge.

For the species of plants common to both Bedouin groups, nutritional exploitation was the most regular practice. All 12 species exploited by the Bischarin for food were also used by the Khushmaan in the same manner. The similar inter-group usage of the 21 species of plants as medicines and for utilitarian purposes was substantially less $(33 \%$ and $29 \%$, respectively) than for nutritional use (Table 1).

Few plants were exploited in distinctly different or opposing ways. Perhaps most notable is Solanum nigrum, which the Bischarin employ as a purgative and for the treatment of heart and liver ailments, while the Khushmaan consider it edible, although they do not consume the plant themselves. The medical usage of Cleome droserifolia also varied from a dermatological

TABLE 1

COMMON USAGE OF 21 PLANT SPECIES BY THE BISCHARIN AND KHUSHMAAN

\begin{tabular}{lll}
\hline $\begin{array}{l}\text { Category of } \\
\text { usage }\end{array}$ & $\begin{array}{l}\text { No. of species } \\
\text { within } \\
\text { category } \\
\text { used in this } \\
\text { manner }\end{array}$ & $\begin{array}{l}\text { Total No. } \\
\text { in category } \\
\text { used } \\
\text { by } \\
\text { both } \\
\text { Bedouin } \\
\text { groups }\end{array}$ \\
\hline $\begin{array}{l}\text { Nutritional } \\
\text { Bischarin }\end{array}$ & $\begin{array}{l}\text { Khushmaan } \\
\text { Khoup }\end{array}$ & $1200 \%)$ \\
$\begin{array}{l}\text { Medicinal } \\
\text { Bischarin }\end{array}$ & $12(57 \%)$ & $3(33 \%)$ \\
Khushmaan & $12(57 \%)$ & \\
Functional & $10(48 \%)$ & \\
Bischarin & $9(43 \%)$ & $2(29 \%)$ \\
Khushmaan & & \\
\hline
\end{tabular}


drug for the Bischarin to a cough suppressant and insect repellant for the Khushmaan.

The lengths of time these two groups have inhabited the Eastern Desert is probably not a critical variable in how they use local plants. The flora of northwestern Arabia, from where the Ma'aza emigrated, is similar to that of the northern Eastern Desert of Egypt (Vesey-Fitzgerald, 1957; Kassas and Zahran, 1965). In fact most of the species of plants reviewed herein are also found in the northern region and the Nefud Desert of Arabia (Vesey-Fitzgerald, 1957; Migahid, 1978). The only exceptions are the genera Ficus, Hyoscyamus, and Pergularia which occur further south. Thus, the Khushmaan Ma'aza had the opportunity to experiment with most elements of the northern Eastern Desert flora long before they migrated to Egypt. We have not been able to locate information on the modern utilization of desert plants by Bedouin living in northwestern Arabia. However, it is likely that the Khushmaan brought with them their own knowledge of the local plants common to the deserts of northwestern Arabia and eastern Egypt.

Another way to explain the similarity in plant usage between these two culturally distinct groups is through the exchange of information rather than independent discovery. The Ababda Bedouin tribe occupies the area between the Khushmaan and Bischarin territories. The Ababda speak Arabic and have mixed Semitic and Hamitic origins. They have contact with both the Bischarin and Khushmaan and could provide the medium of information exchange between these two groups. Further, a few Bischarin families have ventured as far north as Khushmaan territory in search of seasonal pasture, at least in the 20th-century. The festival of the mulid or birthday of Sheikh Shadhli brings together members of the three tribes for a few days every year.

One means of testing parallel origin in the utilization of these plants vs. information exchange is through linguistic comparisons of names. It is assumed that since the languages of the Bischarin and Khushmaan are independently derived, the names of any plant whose usage was introduced by one group to the other should be common between the two groups and in the introducer's tongue. In no case was a Tu Bedawie word found in the Khushmaan lexicon of plant names. There are, however, a few instances of Arabic words appearing in the Bischarin plant vocabulary. For three trees a secondarily used name, almost certainly of Arabic origin, is used by the Bischarin: Acacia raddiana (sayaal), A. ehrenbergiana (sallam), and Phoenix dactylifera (nakhl). In all three cases other words used by the Bischarin for these trees, their fruits or derived parts are from the Tu Bedawie. Thus, it is assumed that the ethnobotanical use of these three trees was not introduced by Arabic speaking people, but rather the Arabic name was secondarily assimilated into Tu Bedawie. A similar situation exists for the Ficus pseudosycomorus fig. The Bischarin use the Arabic word teen for the fruit, but their other terms for the tree and its products are from the Tu Bedawie. The only names recorded from Bischarin informants for two plants, 
Salvadora persica (miswaak) and Solenostemma argel (harjal) which are utilized by both groups in similar ways, are from the Arabic. Based on linguistic grounds, this suggests that Arabic-speaking people introduced the uses of these two plants to the Bischarin.

In two of the 21 cases reviewed in this paper, information exchange cannot be excluded as the factor in the common usage of plants between these distinct cultural groups. Sufficient differences exist in the balance of cases between the ways the Bischarin and Khushmaan use these plants and their respective terminologies that independent development and experimentation is the most likely explanation, rather than education of one group by the other.

One way to eliminate the possible effect of information exchange between different cultures is to study groups that have/had no contact with one another and that live in areas with similar floras. The botanical similarity of the vast Saharo-Sindian phytogeographical region extending from the Maghreb to the Sind-Thar Desert of the Indian sub-continent offers an excellent setting. For example, a comparison of the plant utilization by Bedu inhabiting northeastern Africa to the culturally and linguistically unique nomads of Baluchistan and Sind would allow an assessment of the outcome(s) of truly independent experimentation.

\section{Acknowledgements}

The field work of SMG with the Bischarin was financed by grants from the National Geographic Society (2773-84) and the World Wildlife Fund/ International Union for the Conservation of Nature and Natural Resources (project no. 3612). SMG is grateful to Hassan Mohamed Awad and his late father, Mohamed Awad, for sharing their knowledge of the local biota and the beauty of Gebel Elba. Drs. Nabil el Hadidi, Cairo University Herbarium, and Peter Goldblatt, Missouri Botanical Gardens, kindly identified the plant specimens. JJH's studies with the Khushmaan Ma'aza have been supported by the Fulbright-Hays Doctoral Dissertation Research Abroad program, the American Research Center in Egypt, and the Graduate School and Department of Geography at the University of Texas at Austin. Very special thanks go to Saalih 'Ali of the Khushmaan Ma'aza for guiding JJH to the plants; to many members of the Khushmaan clan for explaining their usefulness; and to Dr. Loutfy Boulos, National Research Center, Dokki, and Mr. Loutfy Mohsen, Cairo University Herbarium, for painstakingly identifying the specimens. We are grateful to Drs. Richard D. Alexander and Robert W. Storer for their critical comments on an earlier version of this paper and $\mathrm{Mr}$. Edward Khounganian for drafting Fig. 1.

\section{References}

Bellakhdar, J. (1978) Médicine traditionelle et toxicologie ouest-saharienne, contribution à l'étude de la pharmacopée marocaine. Edition techniques nord-africaines, Rabat. 
Boulos, L. (1983) Medicinal plants of North Africa. Reference Publications, Algonac, Michigan.

Drar, M. (1936) Enumeration of the plants collected at Gebel Elba during two expeditions. Government Press, Cairo.

Eig, A. (1931/32) Les élements et les groupes phytogéographiques auxiliaires dans la flore palestinienne. Fedde, Repertorium, Beiheft 63; 1-201.

Fahmy, I.R. (1936) Report on Gabel Elba. Egyptian University, Cairo.

Goodman, S.M. (1985) Natural resources and management considerations, Gebel Elba Conservation Area. WWF/IUCN Project no. 3612, Gland.

Hobbs, J.J. (1986) Bedouin reconciliation with the Egyptian desert. Ph.D. dissertation. The University of Texas at Austin, $259 \mathrm{pp}$.

Kassas, M. and Zahran, M.A. (1962) Studies on the ecology of the Red Sea coastal land. I. The district of Gebel Ataqa and el-Galala el-Bahariya. Bulletin de la Société de Géographie d'Égypte 35; 129-175.

Kassas, M. and Zahran, M.A. (1965) Studies on the ecology of the Red Sea coastal land. II. The distriet from el-Galala el-Qibliya to Hurghada. Bulletin de la Saciété de Géographie d'Égypte 38; $155-193$.

Kassas, M. and Zahran, M.A. (1971) Plant life on the coastal mountains of the Red Sea, Egypt. Journal of the Indian Botanical Society 50 a; 571-589.

Keimer, L. (1951) Notes prises chez les BiSarin et les Nubiens d'Assouan. Bulletin de l'Institut d'Égypte 32; 49-101.

Keimer, L. (1952) Notes prises chez les BiSarin et les Nubiens d'Assouan. Bulletin de l'Institut d'Égypte 33; 43-136.

Keimer, L. (1953) Notes prises chez les Bišarin et les Nubiens d'Assouan. Bulletin de l'Institut d'Égypte 34; 329-449.

Mahran, G.H. (1967) Medicinal plants. Anglo-Egyptian Bookshop, Cairo.

Migahid, A.M. (1978) Flora of Saudi Arabia, 2nd edition. Riyadh University Publication, Riyadh.

Murray, G.W. (1935) Sons of Ishmael. G. Routledge \& Sons, London.

Osborn, D. (1968) Notes on the medicinal and other uses of plants in Egypt. Economic Botany 22; $165-177$.

Paul, A. (1954) A history of the Beja tribes of the Sudan. University Press, Cambridge.

Schweinfurth. G. (1869) Pflanzen-namen der Bega-Sprache zwischen Suakin und Berber. Zeitschrift der Gesellschaft für Erdkunde 4; 334-339.

Täckholm, V. (1974) Students' flora of Egypt, 2nd edition. Cairo University, printed in Beirut.

Täckholm, V. and Drar, M. (1954) Flora of Egypt. Vol. III. Cairo University Press, Cairo.

Tregenza, L.A. (1955) The Red Sea Mountains of Egypt. Oxford University Press, London.

Tregenza, L.A. (1958). Egyptian years. Oxford University Press, London.

Vesey-Fitzgerald, D.F. (1957) The vegetation of the Red Sea coast north of Jedda, Saudi Arabia. Jourmal of Ecology 45; 547-562. 